\title{
KEMAMPUAN POWDER ACTIVATED CARBON DALAM MENURUNKAN KADAR BESI TOTAL PADA AIR SUMUR BOR DI KECAMATAN ASTAMBUL KABUPATEN BANJAR TAHUN 2016
}

\author{
Sahliah, Munawar Raharja, Syarifudin \\ Poltekkes Kemenkes Banjarmasin Jurusan Kesehatan Lingkungan \\ Jl. H. Mistar Cokrokusumo No.1A Banjarbaru Kalimantan Selatan 70714 \\ E-mail: lily.sahliah@gmail.com
}

\begin{abstract}
Powder Activated Carbon Capability In Reducing Total Iron Content In Borehole Well Water In Astambul District Banjar Regency Year 2016. Borehole well water in Astambul Regency is proved containing total iron content with physical characteristics such as the yellow-colored deposits and malodorous smell, then it should be do water processing first, which one alternative is using powder activated carbon. This study aims to find out total iron content in borehole well water after given a treatment by adding powder activated carbon according dose variance and contact time. Dependence variable of this study (total iron content), independence variable (variance and contact time with jar test method). This study is true experimental in nature. The study sample is a resident's borehole well water in Tambak Danau Village Astambul District Banjar Regency. Data analysis is using Two-Way Anova statistical test. The study results total iron content in borehole well water before processing $3.35 \mathrm{mg} / \mathrm{L} \mathrm{Fe}$, after processing the decreasing result to the highest dose variance $0.8 \mathrm{gr} / \mathrm{L}$ and contact time 30 minutes results to $0.46 \mathrm{mg} / \mathrm{L} \mathrm{Fe}$ with declining percentage is $76.64 \%$. The statistical test result in p-value $0.000<$ alpha value 0.05 . It means, there is a difference in the decrease of total iron content due dose variance and contact time variance. Meanwhile the result of dose*time p-value $0.354>$ alpha value 0.05 . It means, there is no difference in the decrease of total iron content due to the powder activated carbon dose and contact time variance interaction.
\end{abstract}

Keywords: Total iron content; activated carbon.

\begin{abstract}
Abstrak: Kemampuan Powder Activated Carbon Dalam Menurunkan Kadar Besi Total Pada Air Sumur Bor Di Kecamatan Astambul Kabupaten Banjar Tahun 2016. Air sumur bor di Kecamatan Astambul terbukti mengandung kadar besi total dengan ciri-ciri fisik yaitu ada endapan berwarna kuning dan berbau amis, maka harus dilakukan pengolahan air terlebih dahulu, salah satu alternatif menggunakan powder activated carbon. Penelitian ini bertujuan untuk mengetahui kadar besi total pada air sumur bor sesudah perlakuan penambahan powder activated carbon menurut variasi dosis dan waktu kontak. Variabel terikat pada penelitian ini (kadar besi total), variabel bebas (variasi dosis dan waktu kontak). Jenis penelitian ini besrsifat true experimental. Sampel penelitian adalah air sumur bor salah satu warga di Desa Tambak Danau Kecamatan Astambul Kabupaten Banjar. Analisis data menggunakan uji Two Way Anova. Hasil penelitian kadar besi to tal pada air sumur bor sebelum pengolahan $3,35 \mathrm{mg} / \mathrm{L} \mathrm{Fe}$, setelah dilakukan pengolahan hasil penurunannya yaitu pada variasi dosis tertinggi $0,8 \mathrm{gr} / \mathrm{L}$ dan waktu kontak 30 menit mendapatkan hasil $0,46 \mathrm{mg} / \mathrm{L}$ Fe dengan persentase penurunan yaitu $76,64 \%$. Hasil uji statistik pada nilai $p$-value $0,000<$ nilai alpha 0,05 . Artinya, Ada perbedaan penurunan kadar besi total akibat variasi dosis dan variasi waktu kontak. Sedangkan hasil dosis*waktu nilai $p$ value 0,354 > nilai alpha 0,05. Artinya, tidak ada perbedaan penurunan kadar besi total akibat interaksi dosis powder activated carbon dengan variasi waktu kontak.
\end{abstract}

Kata Kunci: Kadar besi total; activated carbon. 


\section{PENDAHULUAN}

Air merupakan kebutuhan hidup manusia yang sangat penting. Secara langsung air diperlukan untuk minum, memasak, mandi, mencuci dan bersuci. Secara tidak langsung air dibutuhkan sebagai bagian ekosistem yang dengannya kehidupan di bumi dapat berlangsung[1].

Air bersih menurut Peraturan Kepmenkes RI No. 416 Tahun 1990, adalah air yang digunakan untuk keperluan sehari-hari dan akan menjadi air minum setelah dimasak terlebih dahulu. Sebagai batasannya, air bersih adalah air yang memenuhi persyaratan bagi sistem penyediaan air bersih. Adapun persyaratan yang dimaksud adalah persyaratan dari segi kualitas air yang meliputi kualitas fisik, kimia, biologi dan radiologi, sehingga apabila dikonsumsi tidak menimbulkan efek samping. Dalam air bersih, kadar besi (Fe) yang diperbolehkan yakni 1,0 mg/L[2].

Berdasarkan penelitian Mursinah (2005), diperoleh hasil kualitas air bersih dari sumur bor di Desa Tambak Danau Kecamatan Astambul Kabupaten Banjar, secara fisik yaitu kekeruhan 1-8 NTU dan kimia ( $\mathrm{pH}$ 6,74-6,98 dan besi (Fe) pada pengambilan pertama berkisar antara 1,03-1,67 $\mathrm{mg} / \mathrm{L}$ sedangkan pada pengambilan kedua hasilnya berkisar antara 1,28-1,84 mg/L), sehingga dapat dikatakan melebihi atau tidak memenuhi persyaratan sebagai air bersih.

Desa Tambak Danau termasuk dalam wilayah Kecamatan Astambul Kabupaten Banjar. Luas wilayah Desa Tambak Danau $19 \mathrm{~km}^{2}$, terdiri daerah permukiman penduduk dan sebagian untuk lahan pertanian. Desa ini termasuk dalam wilayah kerja Puskesmas Astambul.

Desa Tambak Danau secara geografis memiliki batas-batas wilayah, yaitu: sebelah utara berbatasan dengan Desa Pematang Danau, sebelah selatan berbatasan dengan Desa Pasar Jati, sebelah barat berbatasan dengan Desa Kaliukan dan sebelah timur berbatasan dengan Desa Pematang Hambawang[3].

Demografis Desa Tambak Danau Jumlah penduduknya adalah 1.275 jiwa dengan rincian laki-laki 632 dan wanita berjumlah 643 jiwa. Penduduk Desa Tambak Danau sebagian besar mata pencariannya adalah petani sesuai dengan geografis wilayahnya berupa dataran rendah yang terdiri atas rawa-rawa, tanah tersebut umumnya digunakan untuk pertanian, perkebunan, peternakan, pekarangan dan pemukiman atau perumahan[3].

Hasil survei pendahuluan yang dilakukan pada tanggal 16 Februari 2016 di Desa Tambak Danau Kecamatan Astambul Kabupaten Banjar secara umum masyarakat masih banyak menggunakan air dari sumur bor sebagai air bersih dengan menggunakan pompa mesin. Untuk membuktikan air sumur bor disana mengandung kadar besi maka dilakukan pengambil sampel salah satu air sumur bor warga, lalu dilihat secara fisik diketahui adanya ciri-ciri air yang mengandung zat besi yaitu air berbau amis, air menimbulkan endapan berwarna kemerah bata, serta informasi tentang warga disana bahwa apabila mencuci baju putih akan menimbulkan bercak-bercak kuning pada pakaian, sedangkan hasil pemeriksaan sampel air di laboratorium Politeknik Kesehatan sebelum perlakuan adalah 3,35 $\mathrm{mg} / \mathrm{L} \mathrm{Fe}$, artinya melebihi baku mutu yang ditetapkan. Jadi jika ada satu saja parameter yang tidak memenuhi syarat maka air tesebut tidak layak untuk digunakan.

Ada beberapa proses yang dapat dilakukan untuk menurunkan kadar besi yang tinggi pada air tanah dengan pengamatan secara fisik, kimia dan alami, contoh secara fisik : dengan cara penyaringan menggunakan karbon aktif, secara kimia dengan penambahan kapur, dan secara alami dengan didiamkan. Salah satu alternatif yang dapat dilakukan untuk mengatasi kadar besi yaitu dengan proses adsorpsi (penyerapan). Salah satu sistem adsropsi fisik yang terjadi karena gaya Van der Waals . Pada umumnya adsorben yang digunakan adalah karbon aktif karena mempunyai permukaan yang lebih luas sehingga daya serap yang lebih besar.

Arang aktif merupakan senyawa karbon amorph, yang dapat dihasilkan 
dari bahan-bahan yang mengandung karbon atau dari arang yang diperlakukan dengan cara khusus untuk mendapatkan permukaan yang lebih luas. Arang aktif dapat mengadsorpsi gas dan senyawasenyawa kimia tertentu atau sifat adsorpsinya selektif, tergantung pada besar atau volume pori-pori dan luas permukaan. Daya serap arang aktif sangat besar, yaitu 25- 100\% terhadap berat arang aktif. Karbon aktif tersedia dalam berbagai bentuk misalnya pelet (0.8-5 $\mathrm{mm}$ ) lembaran fiber, bubuk (Powder active carbon, $0.18 \mathrm{~mm}$ atau US mesh 80) dan butiran-butiran kecil (Granular Active carbon, 0.2-5 mm). Powder active carbon lebih mudah dan cepat digunakan dalam pengolahan air dengan sistem pembubuhan yang sederhana. Sedangkan karbon aktif yang berbentuk Granular perlu waktu yang lebih lama misalnya dengan cara filtrasi. Struktur Powder active carbon berpori, semakin kecil poripori arang aktif, mengakibatkan luas permukaan semakin besar. Dengan demikian kecepatan adsorpsi bertambah. Untuk meningkatkan kecepatan adsorpsi, dianjurkan agar menggunakan arang aktif yang telah dihaluskan seperti Powder active carbon ${ }^{1}$.

Berdasarkan penelitian sebelumnya Fatriani Universitas Lambung Mangkurat tahun 2009 yang meneliti tentang pengaruh konsentrasi dan lama perendaman arang aktif tempurung kelapa terhadap kadar besi ( $\mathrm{Fe})$ dan $\mathrm{pH}$ air gambut hasil yang didapat dengan konsentrasi 0,6 gr/L dengan waktu perendaman selama 15 menit sudah dapat menurunkan kadar besi $0,3 \mathrm{mg} / \mathrm{L}$.

Untuk mengurangi kadar besi yang berlebih terutama dalam masalah air tanah, maka perlu dilakukan pengolahan air tanah/air sumur bor. Contohnya masyarakat di desa Tambak Danau Kecamatan Astambul Kabupaten Banjar banyak menggunakan air sumur bor sebagai air bersih tetapi air nya mengandung kadar besi tinggi dan harus dilakukan pengolahan air secara sedehana dengan menggunakan arang aktif untuk menurunkan kadar besi. Maka dari itu peneliti tertarik melakukan penelitian menggunakan powder activated carbon dengan dosis yang telah ditentukan yaitu (0,4 gr/L, 0,5 gr/L, 0,6 gr/L, 0,7 gr/L, 0,8 $\mathrm{gr} / \mathrm{L})$ yang judul uji coba kemampuan powder activated carbon dalam menurunkan kadar besi total pada air sumur bor di Desa Tambak Danau Kecamatan Astambul Kabupaten Banjar tahun 2016.

\section{BAHAN DAN CARA PENELITIAN}

Desain penelitian yang digunakan adalah Pretest and Posttest with Control Group. Karena adanya pemeriksaan kadar besi total setelah dilakukan pengolahan air sumur bor menggunakan variasi dosis powder activated carbon dan variasi waktu kontak. Populasi pada penelitian ini adalah semua air sumur bor yang ada di Desa Tambak Danau Kecamatan Astambul Kabupaten Banjar. Yan g menjadi variabel penelitian ini adalah variasi dosis yaitu 0,4 gr/L, 0,5 gr/L, 0,6 $\mathrm{gr} / \mathrm{L}, 0,7 \mathrm{gr} / \mathrm{L}, 0,8 \mathrm{gr} / \mathrm{L}$ dan variasi waktu kontak yaitu 10 menit, 20 menit, 30 menit. Perhitungan yang diteliti adalah tentang kadar besi total sesudah perlakuan. Metode pengumpulan data yaitu data umum dan data khusus, data umum meliputi gambaran umum kondisi lingkungan sekitar Desa Tambak Danau Kecamatan Astambul Kabupaten Banjar. Data khusus yaitu hasil kadar besi total. Cara penggumpulan data yaitu dengan menyalin data umum Desa Tambak Danau Kecamatan Astambul Kabupaten Banjar sesuai dengan keperluaan peneliti dan melakukan pemeriksaan kadar besi total sesudah dilakukan pengolahan air sumur bor. Pengolahan data yaitu menggunakan analisis uji Two Way Anova.

\section{HASIL PENELITIAN DAN PEMBAHASAN}

Hasil pemeriksaan sarana kualitas air bersih yaitu kadar besi total pada air sumur bor salah satu warga di Desa Tambak Danau Kecamatan Astambul Kabupaten Banjar ini yang dilakukan di laboratorium Kesehatan Lingkungan dapat dilihat pada tabel 1 . 
Tabel 1. Hasil Pengukuran Kadar Besi Total pada Sampel Air Sumur Bor Sebelum Penambahan Powder Activated Carbon

\begin{tabular}{ccc}
\hline Kode Sampel & Kadar Besi Total mg/L Fe & $\begin{array}{c}\text { Kadar Maksimum yang Diperbolehkan } \\
\text { mg/L Fe }\end{array}$ \\
\hline Sebelum & 3,35 & 1,0 \\
\hline
\end{tabular}

Dari tabel 1 menunjukkan bahwa pengukuran kadar besi total pada air sumur bor sebelum pengolahan/penambahan Powder Activated Carbon mendapatkan hasil $3,35 \mathrm{mg} / \mathrm{L} \mathrm{Fe}$ yaitu melebihi standar baku mutu yang dipersyaratan adalah $1,0 \mathrm{mg} / \mathrm{L} \mathrm{Fe}$.
Hasil kadar besi total pada setiap pengulangan sesudah dilakukan pengolahan dengan penambahan Powder Activated Carbon dengan variasi dosis $(0,4$ $\mathrm{gr} / \mathrm{L}, 0,5 \mathrm{gr} / \mathrm{L}, 0,6 \mathrm{gr} / \mathrm{L}, 0,7 \mathrm{gr} / \mathrm{L}, 0,8 \mathrm{gr} / \mathrm{L})$ dan waktu kontak (10 menit, 20 menit, 30 menit) dapat dilihat pada tabel 2 .

Tabel 2. Hasil Pengulangan dan Rata-rata Pengukuran Kadar Besi Total pada Sampel Air Sumur Bor Sesudah Penambahan Powder Activated Carbon

\begin{tabular}{|c|c|c|c|c|c|c|c|c|c|c|}
\hline \multirow{2}{*}{ No } & & \multicolumn{3}{|c|}{10 Menit } & \multicolumn{3}{|c|}{20 Menit } & \multicolumn{3}{|c|}{30 Menit } \\
\hline & Dosis & I & II & Rata $^{2}$ & I & II & Rata $^{2}$ & I & II & Rata $^{2}$ \\
\hline 1 & $0 \mathrm{gr} / \mathrm{L}$ & 2,40 & 2,31 & 2,35 & 2,24 & 2,15 & 2,19 & 1,85 & 2,09 & 1,97 \\
\hline 2 & $0,4 \mathrm{gr} / \mathrm{L}$ & 2,36 & 2,24 & 2,3 & 1,85 & 1,96 & 1,90 & 1,77 & 1,95 & 1,86 \\
\hline 3 & $0,5 \mathrm{gr} / \mathrm{L}$ & 1,94 & 1,87 & 1,90 & 1,79 & 1,50 & 1,64 & 1,50 & 1,81 & 1,65 \\
\hline 4 & $0,6 \mathrm{gr} / \mathrm{L}$ & 1,62 & 1,70 & 1,66 & 1,50 & 1,40 & 1,45 & 1,25 & 1,22 & 1,23 \\
\hline 5 & $0,7 \mathrm{gr} / \mathrm{L}$ & 1,34 & 1,26 & 1,3 & 0,95 & 0,96 & 0,95 & 0,86 & 0,95 & 0,90 \\
\hline 6 & $0,8 \mathrm{gr} / \mathrm{L}$ & 1,09 & 1,06 & 1,07 & 0,62 & 0,68 & 0,65 & 0,44 & 0,48 & 0,46 \\
\hline
\end{tabular}

Dari tabel 2 dapat dilihat pada pengulangan I dan II didapat hasil ratarata pada waktu kontak 10 menit dengan dosis tertinggi $0,8 \mathrm{gr} / \mathrm{L}$ yaitu $1,07 \mathrm{mg} / \mathrm{L}$ $\mathrm{Fe}$, pada waktu kontak 20 menit dengan dosis tertinggi $0,8 \mathrm{gr} / \mathrm{L}$ yaitu $0,65 \mathrm{mg} / \mathrm{L}$ $\mathrm{Fe}$, sedangkan pada waktu kontak 30 menit dengan dosis tertinggi $0,8 \mathrm{gr} / \mathrm{L}$ yaitu $0,46 \mathrm{mg} / \mathrm{L} \mathrm{Fe}$.

Hasil persentase (\%) penurunan kadar besi total sesudah penambahan powder activated carbon dengan variasi dosis dan waktu kontak dapat dilihat pada tabel 3.

Tabel 3. Hasil Persentase(\%) Pengukuran Kadar Besi Total Sebelum dan Sesudah Penambahan Powder Activated Carbon

\begin{tabular}{|c|c|c|c|c|c|c|}
\hline \multirow{2}{*}{$\underbrace{\text { Waktu }}_{\text {Dosis }}$} & \multicolumn{6}{|c|}{$\begin{array}{c}\text { Rata-rata Perlakuan Terhadap Penurunan Kadar Besi Total } \\
\mathrm{mg} / \mathrm{L}\end{array}$} \\
\hline & 10 menit & $\%$ & 20 Menit & $\%$ & 30 Menit & $\%$ \\
\hline $0 \mathrm{gr} / \mathrm{L}$ & 2,35 & 0 & 2,19 & 0 & 1,97 & 0 \\
\hline $0,4 \mathrm{gr} / \mathrm{L}$ & 2,3 & 2,12 & 1,90 & 13,24 & 1,86 & 5,58 \\
\hline $0,5 \mathrm{gr} / \mathrm{L}$ & 1,90 & 19,14 & 1,64 & 25,11 & 1,65 & 16,24 \\
\hline $0,6 \mathrm{gr} / \mathrm{L}$ & 1,66 & 29,36 & 1,45 & 33,78 & 1,23 & 37,56 \\
\hline $0,7 \mathrm{gr} / \mathrm{L}$ & 1,3 & 44,68 & 0,95 & 56,62 & 0,90 & 54,31 \\
\hline $0,8 \mathrm{gr} / \mathrm{L}$ & 1,07 & 54,46 & 0,65 & 70,31 & 0,46 & 76,64 \\
\hline
\end{tabular}

Dari tabel 3 dapat dilihat bahwa hasil rata-rata persentase (\%) penurunan pada waktu kontak 10 menit dengan dosis tertinggi $0,8 \mathrm{gr} / \mathrm{L}$ yaitu $54,46 \%$, pada waktu kontak 20 menit dengan dosis tertinggi $0,8 \mathrm{gr} / \mathrm{L}$ yaitu $70,31 \%$, sedangkan pada waktu kontak 30 menit dengan dosis tertinggi $0,8 \mathrm{gr} / \mathrm{L}$ yaitu 76,64\%.

Asumsi uji anova antara lain data harus normalitas, setelah dilakukan uji normalitas, pada kolom shapiro-wilk didapatkan nilai $\mathrm{p}=0,239$ artinya data 
normal, sehingga uji anova bisa dilakukan untuk uji bivariat.

Data hasil analisis statistik menggunakan uji Anova Two Way Analisys
Of Variance untuk Perbedaan kadar besi total menurut variasi dosis dan waktu kontak pengamatan dapat dilihat pada tabel 4 .

Tabel 4. Kemaknaan Perbedaan Kadar Besi Total Menurut Variasi Dosis dan Waktu Kontak Pengamatan.

\begin{tabular}{cccc}
\hline No & Variasi & Nilai $p$-value & Kemaknaan \\
\hline 1 & Dosis & 0.000 & Bermakna \\
2 & Waktu & 0.000 & Bermakna \\
3 & Dosis*Waktu & 0.354 & Tidak Bermakna \\
\hline
\end{tabular}

Berdasarkan Tabel 4 hasil uji statistik pada variasi dosis, waktu, variasi dosis dengan waktu kontak adalah : Variasi dosis powder activated carbon nilai $p$-value adalah 0,000 yaitu menunjukkan bahwa ada perbedaan secara nyata karena niai $p$-value $<0,05$. Variasi waktu kontak nilai $p$-value adalah 0,000 yaitu menunjukkan bahwa ada perbedaan secara nyata karena niai $p$ value $<0,05$. Interaksi variasi dosis powder activated carbon dengan variasi waktu kontak nilai $p$-value adalah 0,354 yaitu menunjukkan tidak ada perbedaan secara nyata karena niai $p$-value $>0,05$.

\section{PEMBAHASAN}

Berdasarkan tabel 1 adalah hasil uji laboratorium kadar besi total sebelum dilakukan penambahan powder activated carbon air sumur bor berwarna jernih dan berbau amis menandakan bahwa mengandung kadar besi total, sedangkan tabel 5.2 tampilan hasil uji laboratorium kadar besi total sesudah pengolahan dengan menggunakan powder activated carbon air berubah menjadi keruh. Diketahui bahwa sebelum dilakukan pengolahan terhadap air sampel yang diambil dari sumur bor salah satu warga Desa Tambak Danau Kecamatan Astambul Kabupaten Banjar mendapat hasil 3,35 $\mathrm{mg} / \mathrm{L} \mathrm{Fe}$.

Bila dibandingkan menurut Peraturan Menteri Kesehatan RI nomor 416/MENKES/Per/IX/1990 ( Kadar besi total yang dipersyaratkan adalah 1,0 $\mathrm{mg} / \mathrm{L}$ ), maka air sampel yang diambil dari sumur bor salah satu warga Desa Tambak
Danau Kecamatan Astambul Kabupaten Banjar tersebut tidak memenuhi syarat kualitas air sumur bersih ditinjau dari parameter kimia yaitu kadar besi total (Fe).

Kadar besi total pada air permukaan jarang ditemui sedangkan didalam air tanah kadar besi jauh lebih tinggi. Konsentrasi besi yang tinggi ini dapat menodai kain dan pekakas dapur 4 .

Kelarutan besi dalam air dapat disebabkan oleh kedalaman karena air hujan yang turun mengalami infiltrasi kedalam tanah yang mengandung $\mathrm{FeO}$ akan bereaksi $\mathrm{H} 2 \mathrm{O}$ dan $\mathrm{CO} 2$ dalam tanah dan membentuk $\mathrm{Fe}(\mathrm{HCO} 2)$ semakin air tersebut meresap kedalam tanah semakin tinggi kelarutan besi karena berkurangnya oksigen didalam air tersebut4.

Air yang digunakan untuk keperluan sehari-hari harus memenuhi persyaratan kesehatan karena air merupakan suatu sarana utama untuk meningkatkan derajat kesehatan masyarakat, karena air merupakan salah satu media dari berbagai penularan penyakit 5 .

Proses penurunan kadar besi total pada air sumur bor menggunakan powder activated carbon dengan metode jar test dapat menurunkan kadar besi total pada air sumur bor di Desa Tambak danau Kecamatan Astambul Kabupaten Banjar.

Berdasarkan hasil penurunan kadar besi total pada variasi waktu kontak 10 menit dengan dosis tertinggi $0,8 \mathrm{gr} / \mathrm{L}$ yaitu $1,07 \mathrm{mg} / \mathrm{L} \mathrm{Fe}$, pada waktu kontak 20 menit dengan dosis tertinggi 
0,8 gr/L yaitu $0,65 \mathrm{mg} / \mathrm{L} \mathrm{Fe}$, sedangkan pada waktu kontak 30 menit dengan dosis tertinggi $0,8 \mathrm{gr} / \mathrm{L}$ yaitu $0,46 \mathrm{mg} / \mathrm{L} \mathrm{Fe}$. Semakin lama waktu kontak Powder Activated Carbon maka semakin besar penurunan kadar besi total pada air sumur bor.

Powder activated carbon merupakan adsorben yang memiliki diameter pori-pori yang sangat kecil dengan daya serap yang tinggi, adsorpsi dalam arang aktif terjadi secara fisik. Proses adsorpsi terjadi karena sifat yang dimiliki arang aktif sebagai penyerap, penyaring molekul, katalis, dan penukar ion. Adsorpsi secara umum adalah proses mengumpulkan benda-benda terlarut yang terdapat dalam larutan antara dua permukaan seperti zat padat dan zat cair. Walaupun proses tersebut dapat terjadi pada seluruh permukaan benda, maka yang sering terjadi adalah bahan padat yang mengadsorpsi partikel yang berada di dalam air limbah. Bahan yang akan diadsorpsi disebut sebagai adsorbat atau solute sedangkan bahan yang mengadsorpsi disebut sebagai adsorben. Adsorpsi juga merupakan suatu akibat dari medan gaya pada permukaan padatan (adsorben) yang menarik molekul-molekul gas atau cair.

Adsorpsi adalah suatu proses dimana suatu partikel menempel pada suatu permukaan akibat dari adanya perbedaan muatan lemah diantara kedua benda, sehingga akhirnya akan membentuk suatu lapisan tipis partikelpartikel halus pada permukaan tersebut. Adsorpsi zat dari larutan mirip dengan adsorpsi gas oleh zat padat. Adsorpsi bersifat selektif yang diadsorpsi hanya zat terlarut atau pelarut. Bila dalam larutan ada dua zat atau lebih, zat yang satu akan diadsorpsi lebih kuat dari zat yang lain. Semakin tinggi temperatur, semakin kecil daya adsorpsi. Namun demikian, pengaruh temperatur tidak sebesar adsorpsi pada gas 6 .

Adsorpsi yang terjadi pada permukaan zat padat disebabkan oleh gaya valensi atau gaya tarik-menarik dari atom atau molekul pada lapisan paling luar dari zat padat. Adsorpsi ini tergantung pada sifat zat padat yang mengadsorpsi sifat molekul yang diadsorpsi, konsentrasi, tekanan, dan temperatur. Untuk sejumlah besar adsorben dengan luas permukaan tertentu, banyaknya zat yang diadsorpsi tergantung pada konsentrasi atau tekanan dari zat disekitar adsorben. Semakin tinggi konsentrasi, semakin banyak yang diadsorpsi. Proses adsorpsi termasuk pemisahan senyawa dari satu fase yang terakumulasi atau terkumpul pada permukaan lain. Permukaan karbon yang mampu menarik molekul organik misalnya merupakan salah satu contoh mekanisme serapan, begitu juga yang terjadi pada permukaan air dengan udara[7].

Adsorpsi fisika terjadi pada zat yang bersuhu rendah dengan penyerapan relatif rendah. Penyerapan secara fisika relatif tidak spesifik karena kerjanya lambat terhadap daya tarik antara molekul-molekul. Maka dapat dikatakan bahwa gaya yang menahan terserapnya molekul-molekul gas atau cairan oleh zat padat tersebut sama dengan gaya kohesi molekul pada fase cair. Adsorpsi fisika disebabkan oleh antaraksi gaya Van Deer Waals, yaitu dua atau lebih partikel dalam bentuk suspensi yang masing-masing memiliki parameter berbeda, kemudian bergabung menjadi satu sehingga bentuk dan berat molekul gabungan ini menjadi bertambah. Tidak ada redistribusi nyata dari densitas elektron atau pada permukaan substrat.

Pada adsorpsi kimia, partikel melekat pada permukaan dengan membentuk ikatan kimia yang meliputi pengaturan ulang dari densitas elektron yang terbentuk diantara adsorbat dan substrat yang cenderung mencari tempat yang memaksimumkan bilangan koordinasinya dengan substrat. Adsorpsi fisik dan kimia juga dikenali dari perubahan panas yang terjadi. Proses adsorpsi kimia berada dalam orde panas reaksi. Sedangkan panas adsorpsi fisika khususnya pada campuran gas lebih besar dan mencapai 2-3 kali panas kondensasi bahan yang diadsorpsi. 
Bila arang aktif ditambahkan dalam suatu cairan, dibutuhkan waktu untuk mencapai keseimbangan. Pengadukan juga mempengaruhi waktu singgung. Pengadukan dimaksudkan untuk memberikan kesempatan pada partikel arang aktif untuk bersinggungan dengan senyawa serapan[8].

Dari hasil uji perlakuan penambahan powder activated carbon, menunjukkan adanya perbedaan kadar besi total antara kontrol dan perlakuan. Hal ini disebabkan adanya pengaruh dari perlakuan yang diaplikasikan.

Persentase (\%) Penurunan Kadar Besi Total Sesudah Perlakuan menggunakan powder activated carbon.

Pada kontrol terjadi penurunan dari hasil sebelum perlakuan karena adanya perlakuan jar test yaitu dengan terjadinya aerasi saat pengadukan, nilai penurunan kadar besi total sebelum penambahan powder activated carbon berdasarkan waktu kontak 10 menit mendapat hasil $2,35 \mathrm{mg} / \mathrm{L}$ dengan persentase penurunan $29,85 \%$, waktu kontak 20 menit mendapat hasil 2,19 $\mathrm{mg} / \mathrm{L}$ dengan persentase penurunan $34,62 \%$, waktu kontak 30 menit mendapat hasil $1,97 \mathrm{mg} / \mathrm{L}$ dengan persentase penurunan 41,19 \%. Sedangkan pada perlakuan penambahan powder activated carbon nilai penurunan kadar besi total dari dosis yang tertinggi $0,8 \mathrm{gr} / \mathrm{L}$ pada waktu kontak 10 menit yaitu $1,07 \mathrm{mg} / \mathrm{L}$ persentase penurunan $54,46 \%$, dosis yang tertinggi $0,8 \mathrm{gr} / \mathrm{L}$ pada waktu kontak 20 menit yaitu 1,07 $\mathrm{mg} / \mathrm{L}$ persentase penurunan 70,31\%, dosis yang tertinggi $0,8 \mathrm{gr} / \mathrm{L}$ pada waktu kontak 30 menit yaitu $1,07 \mathrm{mg} / \mathrm{L}$ persentase penurunan $76,64 \%$.

Pada tabel 3 adalah hasil uji laboratorium penurunan kadar besi total pada perlakuan menggunakan powder activated carbon dengan metode jar test pada waktu 10 menit hingga 30 menit mengalami penurunan kadar, namun ratarata penurunan kadar tertinggi terjadi pada 30 menit begitu juga dengan kontrol.

Persentase adsorbsi besi bertambah seiring dengan bertambahnya dosis adsorben dan pada saat ada peningkatan dosis adsorben maka ada peningkatan persentase penurunan konsentrasi besi.

Bila arang aktif ditambahkan dalam suatu cairan, dibutuhkan waktu untuk mencapai keseimbangan. Pengadukan juga mempengaruhi waktu singgung. Pengadukan dimaksudkan untuk memberikan kesempatan pada partikel arang aktif untuk bersinggungan dengan senyawa serapan[8].

Adsorpsi dalam arang aktif terjadi secara fisik. Proses adsorpsi terjadi karena sifat yang dimiliki arang aktif sebagai penyerap, penyaring molekul, katalis, dan penukar ion. Adsorpsi secara umum adalah proses mengumpulkan benda-benda terlarut yang terdapat dalam larutan antara dua permukaan seperti zat padat dan zat cair[6].

Ini membukitikan bahwa powder activated carbon dengan metode jar test dapat menurunkan kadar besi total pada air dikarenakan arang yang diproses sedemikian rupa sehingga memiliki daya serap/adsorpsi yang tinggi terhadap bahan yang berbentuk larutan atau uap[1].

Berdasarkan uji statistik pada variasi dosis powder activated carbon nilai p-value adalah 0,000 yaitu menunjukkan bahwa ada perbedaan secara nyata akibat variasi dosis $(0$ gr/L, $0,4 \mathrm{gr} / \mathrm{l}, 0,5 \mathrm{gr} / \mathrm{L}, 0,6 \mathrm{gr} / \mathrm{L}, 0,7 \mathrm{gr} / \mathrm{L}, 0,8$ $\mathrm{gr} / \mathrm{L}$ ) dengan nilai $\mathrm{p}$-value $<0,05$. Artinya, ada perbedaan penurunan kadar besi total akibat dosis yang ditambahkan. Ini membuktikan bahwa variasi dosis powder activated carbon dapat menurunkan kadar besi total sebelum perlakuan mendapatkan hasil $3,35 \mathrm{mg} / \mathrm{L}$ sedangkan sesudah perlakuan dengan penambahan powder activated carbon hasil kadar besi total pada dosis tertinggi $0,8 \mathrm{gr} / \mathrm{L}$ dengan waktu kontak 30 menit mendapatkan hasil $0,46 \mathrm{mg} / \mathrm{L} \mathrm{Fe}$.

Berdasarkan uji statistik pada variasi waktu kontak nilai $p$-value adalah 0,000 menunjukkan bahwa ada perbedaan secara nyata dengan variasi waktu kontak yaitu (10 menit, 20 menit 
dan 30 menit) karena nilai p-value $<0,05$. Artinya, ada perbedaan penurunan kadar besi total akibat variasi waktu kontak yang dilakukan. Ini membuktikan bahwa variasi waktu kontak dengan metode jar test dapat menurunkan kadar besi total pada air sumur bor di Desa Tambak Danau Kecamatan astambul Kabupaten Banjar.

Sedangkan hasil uji statistik untuk interaksi variasi dosis powder activated carbon dengan variasi waktu kontak nilai p-value adalah 0,354 yaitu menunjukkan tidak ada perbedaan secara nyata karena nilai p-value $>0,05$. Artinya, tidak ada perbedaan penurunan kadar besi total akibat interaksi dosis powder activated carbon dengan variasi waktu kontak, karena penurunan tidak terlihat berbeda secara nyata antara variasi dosis dengan variasi waktu kontak.

\section{KESIMPULAN DAN SARAN}

Diketahui kadar besi total sebelum perlakuan penambahan powder activated carbon pada air sumur bor di Desa Tambak Danau Kecamatan Astambul Kabupaten Banjar Tahun 2016 dengan hasil 3,35 mg/L Fe.

Diketahui kadar besi total sesudah perlakuan penambahan powder activated carbon dengan variasi dosis $(0,4$ gr $/ \mathrm{L}, 0,5$ gr/L, 0,6 gr/L, 0,7 gr/L, 0,8 gr/L) dan waktu kontak (10 menit, 20 menit, 30 menit). Didapat hasil pada waktu kontak 10 menit dengan dosis tertinggi $0,8 \mathrm{gr} / \mathrm{L}$ yaitu $1,07 \mathrm{mg} / \mathrm{L} \mathrm{Fe}$, pada waktu kontak 20 menit dengan dosis tertinggi $0,8 \mathrm{gr} / \mathrm{L}$ yaitu $0,65 \mathrm{mg} / \mathrm{L} \mathrm{Fe}$, sedangkan pada waktu kontak 30 menit dengan dosis tertinggi $0,8 \mathrm{gr} / \mathrm{L}$ yaitu $0,46 \mathrm{mg} / \mathrm{L} \mathrm{Fe}$.

Diketahui hasil rata-rata persentase (\%) penurunan dari variasi dosis yang tertinggi $0,8 \mathrm{gr} / \mathrm{L}$ dengan waktu kontak 30 menit yaitu $1,07 \mathrm{mg} / \mathrm{L}$ terjadi persentase penurunan $76,64 \%$.

Diketahui perbedaan penambahan powder activated carbon dengan variasi dosis dan waktu kontak dengan uji statistik menunjukkan nilai $p$-value pada variasi dosis dan waktu adalah $<0,05$ sehingga dapat disimpulkan bahwa ada pebedaan yang bermakna sedangkan pada variasi dosis*waktu adalah $>0,05$ sehingga dapat disimpulkan bahwa tidak ada pebedaan yang bermakna. Analisa lebih lanjut membuktikan hasil kadar keseluruhan berbeda dari kadar sebelumnya. Kadar besi total yang berbeda paling besar yaitu pada dosis 0,8 gr/L dalam waktu kontak 30 menit kadar besi total mengalami penurunan secara tajam dari kadar sebelumnya.

Dapat di sarankan bagi masyarakat di Desa Tambak Danau Kecamatan Astambul Kabupaten Banjar dapat menggunakan powder activated carbon sebagai salah satu alternatif untuk menurunkan kadar besi total pada air sumur bor

\section{KEPUSTAKAAN}

1. Alaerts dan Santika, S, S, 1984. metode penelitian air, Usaha Nasional, Surabaya.

2. Anonim, 2011, Ancaman Polusi Kota Makassar di Ambang Batas, Berita Kota Makassar.

3. Anzwar, A, 1996. Menjaga Mutu pelayanan Kesehatan, Jakarta

4. Basuki, K. R., Setiawan, D., dan Nurimaniwathy, 2008. Penurunan Konsentrasi CO dan NO2 pada Emisi Gas Buang Menggunakan Arang Tempurung Kelapa yang disisipi $\mathrm{TiO} 2$ (online), $4(1)$,

(http://www.digilb.batan.go.id, diakses 4 Februari 2014).

5. Data Batas-batas Kecamatan Astambul, 2013. Kecamatan Astambul Kabupaten Banjar.

6. Depkes RI No. 461/Menkes/IX/1990. Tentang Syarat-syarat dan Pengawasan Kualitas Air Bersih.

7. Hendra, Dj., Pari, G., 2009. Pembuatan Arang Aktif dari Tandan Kosong Kelapa Sawit, Buletin Penelitian Hasil Hutan, Jakarta.

8. Data wilayah kerja Puskesmas Astambul, 2014. Puskesmas Astambul, kecamatan Astambul Kabupaten Banjar.

9. Rahman, 2004. Penyaringan Air Tanah dengan Zeolit Alami untuk Menurunkan Kadar Besi dan Mangan, Jurnal MAKARA. Bogor. 
10. Sembiring, M. T, 2003. Arang aktif. Pengenal dan proses pembuatannya. Sumatra Utara. 

1 